\title{
Efficacy of methomyl and copper sulphate against Eobania vermiculata (Muller) and Helicella vestalis (Preiffer) snail under laboratory and field conditions
}

\author{
Hegab, A.M.I.; Arafa, A. A.I. and Hilmy, A. El-Sayed \\ Plant Protection Research Institute, ARC, Dokki, Giza, Egypt
}

\begin{abstract}
The effect of methomyl and copper sulphate on Eobania vermiculta and Helicella vestalis snails under laboratory and filed conditions was evaluated at Sharkia Governorate. Results under laboratory conditions revealed that, mortality percentages increased with increasing the concentration values and the duration of exposure. All concentrations of methomyl, exhibiting the highest mortality percentages for Eobania vermiculata where recorded $85,92.5,100$ and $100 \%$ with $1,3,5$ and $7 \%$ concentrations after 7 days posttreatment, while the parallel values of copper sulphate were recorded $65,70,80$ and $85 \%$, respectively. It noticed that the concentrations of methomyl were more effective against $H$. vestalis snail were recorded 100 $100 \%$ mortality comparing with the same concentrations of copper sulphate which recorded 47.6- $72.5 \%$ mortality 7 days post-treatment, respectively.

Regarding field experiment it noticed that the initial reduction percentages for two tested compounds were very low where gave 7.55 and $1.13 \%$ for methomyl and copper sulphate against E. vermiculata snail, respectively. The residual effect of the tested compounds was 47.77 and $7.74 \%$ for methomyl and copper sulphate, respectively.
\end{abstract}

Key words: Efficacy, Methomyl , Copper Sulphate, Snail , mortality

\section{Introduction}

The land snails, Eobania vermiculata and Helicella vestalis are considered economic land pests which attack the plants in gardens, crops, vegetables, fruits, seeds, seedlings, plant roots and orchard trees. These pests have chewing mouth parts so they cause very noticeable boles in the leaves of the plant on which they feed and in some cases they bore into other parts of the attached plant Getzin (1965) and Crowell (1967) mentioned that baits are a suitable method for the control of land mollusca.

The harmful land snail species as Monacha cartusiana, Helicella vestalis and Eobania vermiculata cause direct bad effect on the economy resulting from their feeding on various plants, daily activity (Foad, 2005). Many investigators have drawn the attention to control of the land snails using chemical compounds (Kassab and Daoud, 1964; ElOkda, 1978, 1980, 1982b; Hegab, 1998; Hegab, 2003; Ebenso et al., 2005; Ismail and Hegab, 2006; Ismail, 2008 and Hilmy, A. and Hegab (2010). On the other hand, edible baits containing a toxicant are the principal means of delivery of molluscicides in terrestrial gastropod control programs (Getzin (1965) and Crowell (1967). So, certain chemicals were investigated as poisonous baits against land molluscs where this technique was the preference chemical control methods in this respect. The present work was conducted to study the efficacy of methomyl and copper sulphate on Eobania vermiculata and Helicella vestalis under laboratory and field conditions at Sharkia Governorate.

Material and Methods

\section{1- Tested compounds:}

A- Carbamate compounds.

-Trade name: Lannate $90 \%$ W.P.

-Common name: methomyl

-Structure formula:<smiles>CNC(=O)ON=C(C)SC</smiles>

B - Copper sulphate.

$\mathrm{CuSO}_{4} 5 \mathrm{H}_{2} \mathrm{O}$

The pesticide used was supplied from the Central Laboratory for Pesticides, Agricultural Research Center, Giza, Egypt.

Copper sulphate was obtained from ElGamhouria Company for Chemical, Zagazig branch, Egypt.

2- Tested snails:

Healthy adults of brown garden snails, $E$. vermiculata with shell breadth $(26-28 \mathrm{~mm})$ were collected from the ornamental plants in small garden at Zagazig city. The land snails $H$. vestalis healthy with shell breadth $(14-18 \mathrm{~mm})$ were collected from date palm farm at Belbies district, Sharkia Governorate. The snails were transported directly to laboratory in muslin cloth bags and put in glass container $(50 \times 30 \times 30 \mathrm{~cm})$.

Two containers with conditions similar the natural habitat and were fed on wheat bran for 
acclimatization at least four weeks under laboratory conditions (El-Okda, 1981).

\section{3- Laboratory experiments:}

Tested compounds were used with four concentrations 1, 3, 5 and $7 \%$ (a.i) as poisonous baits for pesticide, while for inorganic salt they were applied at the concentration 1, 3, 5 and $7 \%$ (W/W). The baits were prepared by incorporating the appropriate amount of compound and added wheat bran to gave 100 parts of poisonous baits. In all cases, about 10 grams of poisonous baits were spread into each plastic box (3/4 kg. capacity) and 10 snails were introduced. The boxes were closed with musline clothes and secured with rubber band to prevent snails from escaping (El-Okda, 1981). Each treatment was replicated 4 times. Control treatment was prepared using wheat bran baits without any compounds. Mortality percentages were recorded after $1,3,7$ and 15 days for two compounds according to (El-Okda, 1981)

\section{4- Field experiment:}

Two compounds were tested under field conditions in ornamental small garden (15 years old) and infested with E. vermiculata snails at Zagazig city, Sharkia Governorate, during the growing season 2011/ 2012. An area about $700 \mathrm{~m}^{2}$ was selected for this study. Chemicals were used with one concentration as follow: methomyl (Lannate 90\%) was used at the concentration of $1 \%$ while the Copper sulphate was used at the concentration of $7 \%$ as poisonous baits. Baits were prepared by incorporating the appropriate amount with wheat bran and added sugar cane syrup 5\% as attractant substance to give 100 parts from poisonous baits. Baits were distributed on plastic pieces (100 g for each) and around tree trunk before the sundown. Control treatment was designed by the same manner without any chemicals. Each treatment was replicated 5 times. Alive snails were recorded in check and treatments areas before application and after 1, 3, 7 and 15 days post-treatment. Reduction percentages were calculated according to the formula giving by Henderson and Tilton (1955).

\section{Results and Discussion}

Data in Table (1) showed the mortality percentages using methomyl and copper sulphate as poison baits against $E$. vermiculata snails under laboratory conditions.

Mortality percentages increased gradually with increasing the concentration values and the duration of exposure. The highest mortality percentages of methomyl compound were 85, 92.5, 100 and 100\% with $1,3,5$ and $7 \%$ concentrations 7 days posttreatment, respectively while the parallel values of copper sulphate were $65,70,80$ and $85 \%$ with the same concentrations 7 days post-treatment, respectively. The lowest mortality percentage were $(35,37.5,45$ and $72.5 \%)$ and $(10,15,20$ and $32.5 \%)$ for methomyl and copper sulphate, respectively with all concentrations after 1 day of pos-treatment.

Finally, mortality percentages were ranged between 100 - 100 and 95 - 97.5 after 15 days for methomyl and copper sulphate with all concentrations, respectively. Regarding general mean, the highest concentration $(7 \%)$ of methomyl and copper sulphate were gave 91.25 and $68.13 \%$ as general mortality against of $E$. vermiculata

Data in Table (2) illustrated the mortality percentages using methomyl and copper sulphate as poison baits against $H$. vestalis snail under laboratory conditions. Results revealed that In $3^{\text {th }}$ day the concentrations of methomyl and copper sulphate exhibiting the mortality percentages were $(95,97.5$, 97.5 and $97.5 \%$ ) and (37.5, 40, 47.5 and 60\%) against $H$. vestalis snail after post-treatment, respectively.

The highest mortality percentages of the concentration of methomyl compound was the most effective against $H$. vestalis snail comparing with $E$. vermiculata snail in the $7^{\text {th }}$ day, it was $(100,100,100$ and $100 \%)$, respectively, while copper sulphate was the lowest effect against $E$. vermiculata snail comparing with $H$. vestalis snail in $7^{\text {th }}$ day, it was $(65,70,80$ and 85) and (47.5, 52.5, 65 and 72.5), respectively.

After 15 days, mortality percentages were 100 $\%$ for all concentrations of methomyl, while it reached $70,60,72.5$ and $80 \%$ for copper sulphate with all concentrations. The highest concentration (7\%) of methomyl and copper sulphate gave 96.67 and $59.38 \%$ as general mortality against $H$. vestalis.

In conclusion, higher sensitivity of $E$. vermiculata and $H$. vestalis observed to wards the carbamate compound methomyl while, inorganic salt (copper sulphate) appeared to be the least toxic one against two the tested land snails.

Data in Table (3) show the effect of methomyl and copper sulphate against $E$. vermiculata snails under field conditions. Results revealed that the initial reduction percentages for two tested compounds were very low where gave 1.13 and 7.55 $\%$ for copper sulphate and methomyl, respectively. By the time elapsed, reduction percentages increased obviously for methomyl and copper sulphate to reach 78.32 and 11.29 after 15 day, respectively.

Regarding the residual effect of the tested compounds it was 47.77 and $7.79 \%$ for methomyl and copper sulphate, respectively, Generally, it could be reported that methomyl have high molluscicidal activity against $E$. vermeculata comparing with inorganic salt (copper sulphate) which gave low effect under field conditions.

These results are in agreement with the findings of Ismail 1997, found that eight pesticides belonging to different groups; i.e. aldicarb, carbofuran, oxamoyl G., oxamoyl E.C., fenamiphos, fenthion, 
ethoprop and brmoxynil were chosen to evaluate their molluscicidal effect against Monacha cartusiana under laboratory and field conditions. Regarding the laboratory trial, data revealed that oxamyl E.C. proved to be the highest toxic one followed by aldicarb, fenthion, ethoprop, oxamyl E.C., brmoxynil and carbofuran, while fenamiphos showed the lowest effective one. Howere, when these compounds were evaluated under field conditions the opposite was found where the organophosphorous compounds induced the highest effect in this respect. Hegab, et al. (2006) found that the highest concentration of metaldehyde gave $100 \%$ mortality after 7 days compared with the other pesticides which gave 75,30 and $17.5 \%$ for methomyl, abamactin and alpha -cypermethrin, respectively under laboratory conditions. Metaldehyde and methomyl gave highly reduction percentages either during the initial or residual effect under field conditions. Ismail and Hegab, 2006 studied the response of juveniles and adults of terrestrial snails Eobania vermiculata for certain chemicals under laboratory and field conditions. Results revealed that juveniles were more sensitive than adults to inorganic salts, where mortality percentages for copper sulfate were higher the tested inorganic salts. Regarding the susceptibility to pesticides the juveniles were more sensitive than adults for abamectin and methomyl. Hilmy and Hegab, 2010 found that $M$. cartusiana were more sensitive towards the tested pesticides than $E$. vermiculata at laboratory 7 days $/ \mathrm{LC}_{50}$ values for $M$. cartusiana were 474, 6329, 13612 and 17028 ppm when treated with nemacur, lebaycid, sencor and antracol, respectively. The population reduction percentages after seven days post-treatment were 89.3, 73.8, 29.7 and 25.0 for $M$. cartusiana treated with lebaycid, nemacur, sencor and antracol, respectively. Ismail $\boldsymbol{e t}$ al. (2010) reported that metaldehyde recorded highly efficacy than the other tested pesticides (copper hydroxide, methomyl and diazinon ). However, high mortality percentage $(100 \%)$ was obtained after 7 days at concentration $2 \%$ under the laboratory conditions, while under field conditions, methomyl induced a higher effect on the population reduction $(73.19 \%)$ than metaldehyde. Copper hydroxide was found to be the lowest effective one against $M$. cartusiana snail under both laboratory and field conditions. Finally, Shetaia et al. (2013) reoorted that agrinate $24 \%$ S. L. (methomyl) gave the highest effect against Monacha cartusiana snail either under laboratory and files conditions where mortality percentage reached 86.33 and 77.17 , respectively.

Table 1. Mortality percentages of Eobania vermiculata using methomyl and copper sulphate as poison baits under laboratory conditions.

\begin{tabular}{|c|c|c|c|c|c|c|}
\hline \multirow[b]{2}{*}{ Compounds } & \multirow[b]{2}{*}{ Conc. \% } & \multicolumn{4}{|c|}{ \% Mortality after indicated days } & \multirow[t]{2}{*}{ General mean } \\
\hline & & 1 day & 3 days & 7 days & 15 days & \\
\hline \multirow{4}{*}{ methomyl } & 1 & 35 & 67.5 & 85 & 100 & 71.87 \\
\hline & 3 & 37.5 & 75 & 92.5 & 100 & 76.25 \\
\hline & 5 & 45 & 82.5 & 100 & - & 81.87 \\
\hline & 7 & 72.5 & 92.5 & 100 & - & 91.25 \\
\hline \multirow{4}{*}{$\begin{array}{l}\text { Copper } \\
\text { sulphate }\end{array}$} & 1 & 10 & 45 & 65 & 95 & 53.75 \\
\hline & 3 & 15 & 50 & 70 & 90 & 56.25 \\
\hline & 5 & 20 & 52.5 & 80 & 95 & 61.88 \\
\hline & 7 & 32.5 & 57.5 & 85 & 97.5 & 68.13 \\
\hline
\end{tabular}

Table 2. Mortality percentages of Helicella vestalis using methomyl and copper sulphate as poison baits under laboratory conditions.

\begin{tabular}{|c|c|c|c|c|c|c|}
\hline \multirow[b]{2}{*}{ Compounds } & \multirow[b]{2}{*}{ Conc. \% } & \multicolumn{4}{|c|}{ \% Mortality after indicated days } & \multirow[t]{2}{*}{ General mean } \\
\hline & & 1 day & 3 days & 7 days & 15 days & \\
\hline \multirow{4}{*}{ methomyl } & 1 & 60 & 95 & 100 & 100 & 88.75 \\
\hline & 3 & 65 & 97.5 & 100 & 100 & 90.62 \\
\hline & 5 & 70 & 97.5 & 100 & 100 & 91.87 \\
\hline & 7 & 92.5 & 97.5 & 100 & 100 & 97.5 \\
\hline \multirow{4}{*}{ Copper sulphate } & 1 & 12.5 & 37.5 & 47.5 & 70 & 41.88 \\
\hline & 3 & 15 & 40 & 52.5 & 60 & 41.88 \\
\hline & 5 & 17.5 & 47.5 & 65 & 72.5 & 50.63 \\
\hline & 7 & 25 & 60 & 72.5 & 80 & 59.38 \\
\hline
\end{tabular}


Table 3. Efficacy of methomyl and copper sulphate against E. vermiculata snails under field conditions at sharkia Governorate.

\begin{tabular}{|c|c|c|c|c|c|c|c|}
\hline \multirow[t]{2}{*}{ Compounds } & \multicolumn{2}{|c|}{$\begin{array}{l}\% \text { reduction after } \\
\text { indicated days }\end{array}$} & \multirow{2}{*}{$\begin{array}{l}\text { Initial effect } \\
\text { (during the } \\
\text { first three } \\
\text { days) } \%\end{array}$} & \multicolumn{3}{|c|}{$\begin{array}{c}\% \text { reduction after indicated } \\
\text { days }\end{array}$} & \multirow{2}{*}{$\begin{array}{c}\text { Residual effect } \\
\text { (during the rest } \\
\text { period) } \\
\%\end{array}$} \\
\hline & 1 & 3 & & 5 & 7 & 15 & \\
\hline Methomyl & 0.80 & 14.30 & 7.55 & 29.30 & 35.69 & 78.32 & 47.77 \\
\hline Copper sulphate & 0.58 & 1.68 & 1.13 & 3.42 & 8.67 & 11.29 & 7.79 \\
\hline
\end{tabular}

References

Crowell, H.H. (1967). Slug and snail control with experimental poison baits. J. Econ. Entomol. 60 (4): 1048- 1049.

Ebenso, I.E., B.ITA, E.P. Umoren, M.TTA, W. BINANG, G. Edet, M.Izah, I.O. udo, G. Ibango and E.E. Uk pong. 2005. Effect of carbamate molluscicide on African Giant land snail Limicolaria aurora. J. Apple, Sci. Environ. Mgt Vol. 9 (1) 99 - 102.

El-Okda, M.M. K. (1982b. Efficacy of certain local formulated bran baits against the land mollusca under pear and orange trees. In Egypt. Egypt's National Conf. of Entomology, Dec. 1982, 11: 589- 597.

El-Okda, M.M.K. (1978). Mesurol pellet bait as a control agent for terrestrial snails and slugs at Alexandria region, A.R.E. Agric. Rec. Rev. Egypt, 57(1): 197 - 201.

El-Okda, M.M.K. (1980). Land snails of economic importance on vegetable crops at Alexandria and neighbouring region. Agric. Res. Rev., 58 (1): $79-85$.

El-Okda, M.M.K. (1981). Response of two land mollusca to certain insecticides. Bull. Ent. Soc. Egypt. Econ. Ser. 12: 53-57.

Foad, M. M. (2005). Histological changes induced in the mucus glands of brown garden snails Eobania vermiculata treated with malathion and methomyl pesticides. Egypt. J. Agric. Res., 83 (1) $251-259$.

Getzin, D. (1965). Control of the gray garden slug with bait formulation of carbamate molluscicides. J. Econ. Entomol., 58: 158 - 9 .

Hegab, A.M. I. (1998). The efficacy of certain pesticides against the land snail Eobania vermiculata (Muller) under field conditions at Sharkia Governorate. Egypt. J. Appl. Sci., 13 (12): 266- 276.

Hegab, A.M.I. (2003). Efficacy of certain pesticides against Monacha cartusiana (Muller) snails under laboratory and field conditions in Sharkia Governorate. Zagazig. J. Agric. Res., 30(5): $2009-2020$.

Hegab, A.M.I.; El-Massry, S.A.A. and Ghatwary, W.G.T. (2006). Evaluation of certain pesticides and some plants dry leafe powders against Monacha cartusiana (Muller) snail Egypt. J. of Appl. Sci., 21 (1) 2006.
Henderson, G.F. and Tilton, E.W. (1955). Test with acaricides against the brown wheat mite. J. Econ. Entomol., 48 : 157 - 161.

Hilmy, A. El-Sayed and Hegab, A.M.I. (2010). Sensitivity of two land snail species (Monacha cartusiana and Eobania vermiculata) against some pesticides under laboratory and field conditions at Sharkia Governorate Egypt. J. Agric. Res., 88 (4) 1185 - 1195.

Ismail, Sh.A.A. (1997). Ecology, Biology and control of certain terrestrial snails infesting some vegetable and field crops in Sharkia Governorate. Ph.D. Thesis Fac. Agric. Zagazig Univ., 128.

Ismail, Sh.A.A. 2008. Daily activity, movement and food consumption of Monacha cartusiana snails under laboratory and field conditions in Sharkia Governorate. Egypt. J. of Appl. Sci., 23: 700-708.

Ismail, Sh.A.A. and Hegab, A.M.I. (2006). Response of juveniles and adults of the brown garden snail, Eobania vermiculata (Muller) to certain chemicals. Egypt. J. of Appl. Sci., 21 (8).

Ismail, Sh.A.A.; Shetaia, S.Z.S. and Samah, M. Abdel Kader (2010). Effect of heem extract, neemazal T.S. on two land snails species under laboratory condition. J. Plant Prot. and Path., Mansoura Univ., 1(10): 799-806.

Kassab, A. and Daoud, H. (1964). Notes on the biology and control of land snails of economic importance in the U.A.R.J. Agric. Res., Rev. Cairo, $42: 77-98$.

Shetaia, S. S. Z. S; Arafa, A. A. I. and Abd- ElAtty, S. F. (2013). Efficacy of certain compound against the glassy clover snail Monacha cartusiana (Muller)at Sharkia Governorate. J. Plant Prot. and Path., Mansoura Univ., 41: 67-73. 


\section{كفاءة الميثوميل وكبريتات النحاس ضد قوقعى إيويانيا فيرميكيولاتا وهيليسلا فيستاليس تحت الظروف المعلية والحقلية}

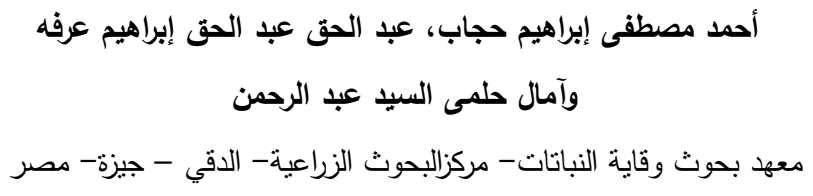

Eobania

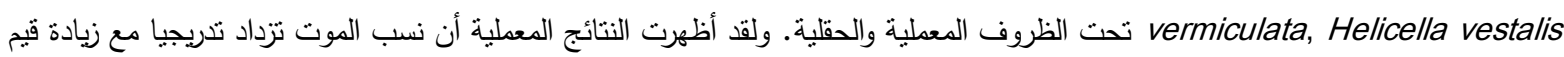
التركيزات ومدة التعرض وقد وجد أن جميع تركيزات مركب الميثوميل كانت أكثر كفاءة حيث سجلت نسب موت كالتالي 95، 92.5، 100،100\% بعد سبعة أيام من المعاملة بينما وجد أن تركيزات كبريتات النحاس انحصر تأثيرها من 65، 70، 80، 85 \% موت بعد نفس الفنرة

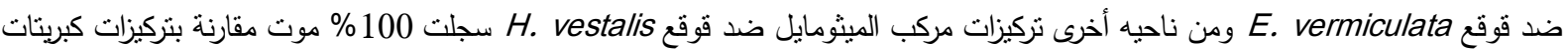

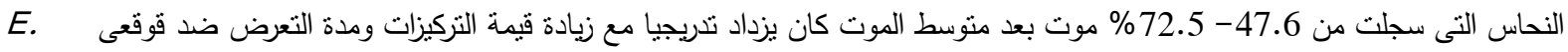
vermiculata, H. vestalis

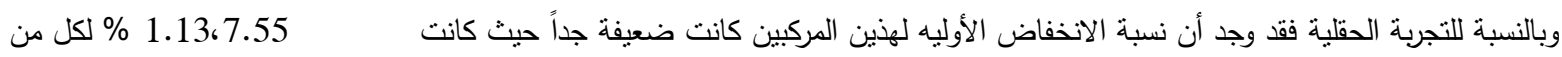
مركب كبريتات النحاس ومركب الميثومايل ضد قوقع E. vermiculata تحت الظروف الحقلية. بينما الثأثير الباقى للمركبات المختبرة كانت

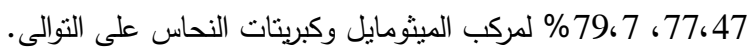

